\title{
Effect of four varieties of mulberry on biochemistry and nutritional physiology of mulberry pyralid, Glyphodes pyloalis Walker (Lepidoptera: Pyralidae)
}

\author{
M. Oftadeh, J.J. Sendi, A. Zibaee, B. Valizadeh \\ Department of Plant Protection, University of Guilan, Rasht, Iran
}

\begin{abstract}
The effects of four mulberry varieties (Kenmochi, Ichinose, Shin Ichinose, Mahalii) on nutritional indices and digestive proteolytic and amylolytic activities of Glyphodes pyloalis Walker (Lepidoptera: Pyralidae) were determined at $24 \pm 1^{\circ} \mathrm{C}, 75 \pm 5 \% \mathrm{RH}$ and a photoperiod of 16:8 L:D. Fifth instar larvae reared on Shin Ichinose showed the highest efficiency of conversion of digested food and efficiency of conversion of ingested food $(3.82 \pm 0.16 \%$ and $3.11 \pm 0.07 \%$, respectively). Approximate digestibility values of the fourth instar larvae were highest $(95.23 \pm 0.73 \%)$ and lowest $(91.77 \pm 1.45 \%)$ on Kenmochi and Shin Ichinose, respectively. The fifth instar larvae fed on Kenmochi had the highest consumption index $(4.6 \pm 0.73)$ and lowest relative growth rate $(0.03 \pm 0.10)$, respectively. Our results showed that the highest protease activity in optimal $\mathrm{pH}$ was on Malalii variety $(0.97 \mathrm{U} / \mathrm{mg})$ and the lowest was on Kenmochi $(0.75 \mathrm{U} / \mathrm{mg})$. In addition, the highest amylase activity in optimal pH was on Mahalii $(0.17 \mathrm{U} / \mathrm{mg})$ and lowest on Kenmochi $(0.103 \mathrm{U} / \mathrm{mg})$. Specific proteolytic analysis showed that larvae feeding on Mahalii had the highest activity of trypsin and elastase ( 2.30 and $2.13 \mathrm{U} / \mathrm{mg}$, respectively). This research showed that plasticity in food utilization and enzyme activity is functionally relevant to host plant cultivars. The results of nutritional indices and activity of digestive enzymes indicated that Kenmochi was an unsuitable host for feeding of Glyphodes pyloalis.
\end{abstract}

Correspondence: Jalal Jalali Sendi, Department of Plant Protection, Faculty of Agricultural Sciences, University of Guilan, Rasht, 416351314, Iran. Tel.: +981316690817 - Fax: +981316690281.

E-mail: jjalali@guilan.ac.ir

Key words: Glyphodes pyloalis, feeding indices, digestive enzymes.

Received for publication: 2 May 2013.

Revision received: 9 November 2013.

Accepted for publication: 25 November 2013.

(O) Copyright M. Oftadeh et al., 2014

Licensee PAGEPress, Italy

Journal of Entomological and Acarological Research 2014; $46: 1633$

doi:10.4081/jear.2014.1633

This article is distributed under the terms of the Creative Commons Attribution Noncommercial License (by-nc 3.0) which permits any noncommercial use, distribution, and reproduction in any medium, provided the original author(s) and source are credited.

\section{Introduction}

Mulberry is the sole host for silkworm (Bombyx mori L) rearing and is also used for shade trees in cities (Kumar et al., 2002). The lesser mulberry pyralid, Glyphodes pyloalis Walker (Lepidoptera: Pyralidae) is considered a serious pest of mulberry in India, China, Korea, Japan, Malaysia, Pakistan, Uzbekistan and Burma (Madyarov et al., 2006). This pest has caused severe damage to mulberry plantings in northern Iran and has turned into a serious concern for the silk industry (Khosravi \& Sendi, 2010). Larvae form threads on the outer part of mulberry leaves and feed on the mesophyll from under those threads, leaving only a network of epidermis (Aruga, 1994). If leaves infected with excreta of larvae are fed to silkworms, they develop constipation and are unable to defecate (Aruga, 1994). In addition, $G$. pyloalis larvae are considered alternate hosts of Bombyx densoviruses and picornaviruses (Watanabe et al., 1988)

Nutrition is the interaction of physiological processes and ecology, so it is directly associated with natural selection as well as competition for food (Sheikher et al., 2001; Zhu et al., 2005; Xue et al., 2010). In numerous studies of the relationships between insect pests and plants, attempts have been made to quantify the efficiency with which insects use their food plants (David \& Gardiner, 1962; Sheikher et al., 2001; Xue et al., 2010). Together with data on the rate of food ingestion and growth, food utilisation efficiency is an important component of herbivore performance (Slansky \& Scriber, 1985).

The quality and quantity of food consumed could affect the growth, development, and reproduction of insects (Scriber \& Slansky, 1981).

Of the tools of pest management, host plant resistance is important in terms of being both economically and environmentally acceptable. Therefore, as a method of controlling pest insects, host plant resistance is not only favourable to the environment, but also reduces expenses for growers (Li et al., 2004). The factors determining nutrient availability for growth and maintenance over a given period of development are the amount and type of food consumed and the efficiency with which it is utilized (Barton Browme \& Raubenheimer, 2003).

The study of host plant resistance can play an important role in identifying anti-digestive or antifeedant compounds and their further use in pest management strategies (Lewis et al.,1997). A possible strategy to control insect pests is to produce crops with elevated levels of endogenous resistance. One such approach has been to overexpress plant proteins that are known to play a role in plant defence against herbivores (Hosseininaveh et al., 2007). Many plants respond to insect feeding by the synthesis of protease inhibitors (PIs) (Ryan, 1990). Plant PIs have been shown to inhibit gut proteases of insects and prevent larval growth and development when delivered in artificial diets (Johnston et al., 1993) or when expressed in transgenic crops (Hilder, 1987). Efforts are being made to explore their use in developing insect resistance in susceptible crop plants (Sharma et al., 2000). However, as a first step to achieving this goal, an understanding of how 
digestive enzymes function is essential to plan strategies for successful and sustainable implementation of PI-based control methods (Franco et al., 2002). Insect digestive proteases catalyze the release of peptides and amino acids from dietary proteins in the insect digestive canal to meet its nutritional requirements (Terra \& Ferreira, 1994).

The lepidopteran larval midgut has been shown to have complex proteolytic activities including trypsins, chymotrypsins, elastases, cathepsin-B-like proteases, aminopeptidases, and carboxypeptidases that are all required in protein digestion. Lepidopteran insects mainly depend on serine proteases for protein digestion (Bown et al., 1997). The other important classes of digestive enzymes from these insects include $\alpha$-amylases, which are also the main digestive enzymes of many other insects that feed absolutely on starchy seeds throughout their life (Pereira et al., 1999). The $\alpha$-amylases ( $\alpha$-1, four glucan four glucanohydrolases; EC 3.2.1.1) catalyze hydrolysis of $\alpha$-D-(1,4)-glucan linkage in starch components glycogen, and other different associated carbohydrates to supply an energy source (Franco et al., 2000).

In insects, the activity of digestive enzymes such as proteases and $\alpha$-amylases depends on the nature of food sources or chemical compounds ingested (Mendiola-Olaya et al., 2000). Protease and $\alpha$-amylase activities in crude extracts of larval guts of different lepidopteran species have been described (Zibaee et al., 2008).

Study of the insect digestive system is an important method for discovering new control techniques in integrated pest management programs (Lawerence \& Koundal, 2002). Many factors are involved in the host preference of insects. Among the most important are plant species and regional plant diversity (Davidson et al., 2001), chemical composition of leaves (Foss \& Riseke, 2003), and leaf age, which itself is the cause of physical and chemical changes (Meyer \& Montgomery, 2004).

The goal of this research was to compare nutritional indices and activity of digestive enzymes in $G$. pyloalis larvae reared on different host plants, and to determine how these parameters change after an additional instar and in response to different hosts.

\section{Materials and methods}

\section{Plant sources}

Four host plants were used in this study, including Kenmochi, Ichinose, Shin Ichinose and Mahalii. These varieties were selected because they are the most important economic varieties used in Iran to rear silkworms.

\section{Insect rearing}

G. pyloalis larvae were collected from mulberry orchards near the city of Rasht in northern Iran. They were reared on fresh mulberry leaves (different host plants) in the laboratory at $24 \pm 1^{\circ} \mathrm{C}, 75 \pm 5 \% \mathrm{RH}$ and 16:8 (L:D) $h$ photoperiod in transparent plastic boxes $(18 \times 15 \times 7$ $\mathrm{cm})$ covered with muslin for aeration. As adults emerged, they were separated and placed in transparent plastic boxes $(18 \times 7 \mathrm{~cm})$ with a $10 \%$ honey solution on cotton wool for feeding, and mulberry leaves were provided for oviposition.

\section{Nutritional indices}

Nutritional indices were determined using second to fifth instars, which were easier for measuring these indices than on the $1^{\text {st }}$ instar. Ten newly emerged second instar larvae that had been reared on each of the four varieties of mulberry as host plants were selected and provided with 10 fresh leaves from each of the four hosts; they were individually weighed and maintained in small plastic tubes $(2 \times 5 \mathrm{~cm})$ until they stopped feeding before molting to the next instar. This method was used for other larval instars as well. The initial fresh food and the food and feces remaining at the end of each experiment were weighed daily. The quantity of food ingested was determined by subtracting the diet remaining at the end of each experiment from the total weight of diet provided. The weight of feces produced by the larvae fed on each mulberry variety was recorded daily. To find the dry weights of the pods, feces, and larval to adult stages, extra specimens (20 specimens for each) were weighed, oven-dried $\left(48 \mathrm{~h}\right.$ at $\left.60^{\circ} \mathrm{C}\right)$, and then re-weighed to establish a percentage of their dry weight.

Food utilization rates were then calculated based on the following formulas of Waldbauer (1968): i) consumption index (CI): calculated on the basis of the rate of intake relative to the mean weight of the larva during the feeding period, according to the following formula: $\mathrm{CI}=\mathrm{F} / \mathrm{TA}$; ii) relative growth rate (RGR): calculated as: $\mathrm{RGR}=\mathrm{G} / \mathrm{TA}$; iii) efficiency of conversion of ingested food (ECI): the efficiency of conversion of ingested food to body substance is calculated as: $\mathrm{ECI}=\mathrm{WG} / \mathrm{FI} \times 100$; iv) approximate digestibility (AD): the approximate digestibility is calculated as: $\mathrm{AD}=\mathrm{FI}-\mathrm{WF} / \mathrm{FI} \times 100$; v) efficiency of conversion of digested food (ECD): the efficiency with which digested food is converted to body substance is calculated as: ECD=WG/FI$\mathrm{WF} \times 100$.

Where is $\mathrm{A}=$ mean fresh weight of the larva during the feeding period, $\mathrm{F}=$ fresh weight of food eaten, $\mathrm{T}$ =duration of feeding period (days), $\mathrm{G}=$ fresh weight gain of the larva during the feeding period, $\mathrm{WG}=$ weight gained, $\mathrm{FI}=$ =weight of food ingested, $\mathrm{WF}=$ =weight of feces.

\section{Biochemical assessments}

The guts of fifth instar larvae were used to measure proteolytic and amylolytic activities, and the whole body to measure other biochemical assessments as follows: fifth-instar larvae reared on different hosts were cold anesthetized and quickly dissected under a stereomicroscope. The midguts were then cleaned by deletion of unneeded tissues. The midguts, including contents, were collected into a known amount of distilled water and homogenized with a handheld glass grinder on ice, and the homogenates were centrifuged at $16,000 \times \mathrm{g}$ for $10 \mathrm{~min}$ at $4^{\circ} \mathrm{C}$. The resulting supernatant was stored at $-20^{\circ} \mathrm{C}$ for later protease and amylase assays. Each biochemical analysis was repeated 3 times.

General proteolytic activity present in the midgut of $G$. pyloalis larvae fed on different hosts was determined using azocasein as a substrate at an optimum $\mathrm{pH}$. A universal buffer system (50 mM sodium phosphate-borate) was used to determine the $\mathrm{pH}$ optimum of proteolytic activity over a $\mathrm{pH}$ range of 7-12. To determine the azocaseinolytic activity, the reaction mixture containing $80 \mu \mathrm{L}$ of $1.5 \%$ azocasein solution in $50 \mathrm{mM}$ universal buffer $(\mathrm{pH} \mathrm{12})$ and $50 \mu \mathrm{L}$ of crude enzyme was incubated at $37^{\circ} \mathrm{C}$ for $50 \mathrm{~min}$. Proteolysis was terminated by the addition of $100 \mu \mathrm{L}$ of $30 \%$ trichloroacetic acid (TCA) followed by cooling at $4{ }^{\circ} \mathrm{C}$ for $30 \mathrm{~min}$ and centrifugation at $16,000 \times \mathrm{g}$ for $10 \mathrm{~min}$. An equal volume of $2 \mathrm{M} \mathrm{NaOH}$ was added to the supernatant, and the absorbance was measured at $440 \mathrm{~nm}$. Appropriate blanks in which TCA had been added prior to the substrate were prepared for each assay. Unit activity was expressed as an increase in optical density $\mathrm{mg}^{-1}$ protein of the tissue $\mathrm{min}^{-1}$ due to azocasein proteolysis (Vinokurou et al., 2007).

Digestive trypsin-, chymotrypsin- and elastase-like activities of the larvae fed on either all varieties of mulberry were estimated using final concentrations of $1 \mathrm{mM}$ BApNA, 1mM SAAPFpNA and $1 \mathrm{mM}$ SAAApNA as substrates, respectively. A reaction mixture consisted of $20 \mu \mathrm{L}$ of enzyme extract for trypsin- and elastase-like activities and $10 \mu \mathrm{L}$ of enzyme extract for chymotrypsin-like activity, $75 \mu \mathrm{L}$ of universal buffer at the appropriate $\mathrm{pH}$ optimum ( $\mathrm{pH} 10.5$ for trypsin- and chymotrypsinlike enzymes and $\mathrm{pH} 11$ for elastase-like enzyme) and $5 \mu \mathrm{L}$ of the above-mentioned substrate. Absorbance was then measured at $405 \mathrm{~nm}$ for $40 \mathrm{~min}$ (at 2, 1 and 4 min time intervals respectively). All assays were carried out in triplicate against appropriate blanks.

The $\alpha$-amylase activity was measured using the procedure of Bernfeld (1955), with $1 \%$ soluble starch as substrate. A quantity of 50 
$\mu \mathrm{L}$ of the enzyme was incubated with $250 \mu \mathrm{L}$ of universal buffer $(\mathrm{pH}$ 10) and $20 \mu \mathrm{L}$ of soluble starch for $30 \mathrm{~min}$ at $37^{\circ} \mathrm{C}$. The reaction was terminated by addition of $50 \mu \mathrm{L}$ DNS and heating in boiling water for $10 \mathrm{~min}$. The absorbance was then read at $540 \mathrm{~nm}$ after cooling on ice. One unit of amylase activity was defined as the amount of enzyme required to produce $1 \mathrm{mg}$ of maltose in $30 \mathrm{~min}$ at $37^{\circ} \mathrm{C}$ under the given assay conditions.

Alanine aminotransferase (ALT) and aspartate aminotransferase (AST) were measured using Thomas' (1998) procedure. This assay was done by AST and ALT kit (Biochem Co., Tehran, Iran). The absorption was read at $340 \mathrm{~nm}$.

Assays of estimation of acid (ACP) and alkaline phosphatases (ALP) were carried out as described by Bessey et al. (1946). The buffered substrate (phosphate buffer, $0.02 \mathrm{~m}, \mathrm{pH} 7.2$ ) was incubated with the samples for $30 \mathrm{~min}$. Alkali was added to stop the reaction and to adjust the $\mathrm{pH}$ for the determination of concentration of the product formed. The spectral absorbance of p-nitrophenolate was maximal at $310 \mathrm{~nm}$. The molar absorbance of p-nitrophenolate at $400 \mathrm{~nm}$ is about double that of p-nitrophenyl phosphate at $310 \mathrm{~nm}$. On converting the p-nitrophenolate into pnitrophenol by acidification, the absorption maximum is shifted to about $320 \mathrm{~nm}$ with no detectable absorption at $400 \mathrm{~nm}$.

Glucose was analyzed as described by Sigert (1987). Protein was measured based on Bradford's (1976) method and by utilizing a total protein assay kit (Biochem Co.). In this method, proteins made a complex purplish blue with an alkaline copper solution, for which the absorption value was read at $540 \mathrm{~nm}$.

To measure the total cholesterol of hemolymph, Richmond's (1973) method was conducted. The principles of this method are based on hydrolysis of cholesterol esters by cholesterol oxidase, cholesterol esterase and peroxidase.

Glycogen and trehalose content were assessed using the method of Van Handel (1965). This method separates glycogen and trehalose. Trehalose and glycogen were similarly assayed using the anthrone-sulfuric acid method.

\section{Chemical analysis of the leaves}

Leaves from all four mulberry trees were collected during the experimental period in July 2012, dried in the shade, and prepared for chemical analysis. For phosphorous, calcium and potassium, dry ashing and mixing with $\mathrm{HCl}$ was first performed. Total organic nitrogen content was determined by the micro-Kjeldahl method, potassium content was measured by flame photometry, using a lithium internal standard, and phosphorus content was determined using the colorimetric method with blue coloured acid ascorbic and read at $880 \mathrm{~nm}$. For measuring calcium, the compleximetric method was used.

\section{Statistical analysis}

Nutritional indices of $G$. pyloalis reared on different hosts were analyzed with one-way ANOVA using the statistical software Minitab ver. 14.0 (Minitab Inc., Philadelphia, PA, USA. http://www.minitab.com; 1994) to determine similarities and significant differences. Statistical differences among the means were assessed using an LSD test at $\alpha=0.01$. Data were tested for normality before analysis. The data from other experiments were subjected to analysis of variance (ANOVA) using SAS software. The least significant differences among treatments were compared using Tukey's multiple range test (SAS Institute, Cary, NC, USA; 1997). Differences among means were considered significant at $\mathrm{P} \leq 0.01$.

\section{Results}

\section{Nutritional indices}

The results of the nutritional indices of second- fifth larval instars of $G$. pyloalis are shown in Tables 1-4. Nutritional indices of the second instar larvae of $G$. pyloalis were significantly different for different host plants. The larvae reared on Kenmochi showed the highest value of ECD $(\mathrm{F}=17.70 ; \mathrm{df}=3 ; \mathrm{P}<0.0007)(1.15 \pm 0.12 \%)$ and $\mathrm{CI}(\mathrm{F}=143.38 ; \mathrm{df}=3$; $\mathrm{P}<0.0001)(7.14 \pm 0.9)$. However, the lowest value of ECD $(\mathrm{F}=0.91 ; \mathrm{d}=3$; $\mathrm{P}<0.0004)$ and $\mathrm{CI}(\mathrm{F}=0.35 ; \mathrm{d}=3 ; \mathrm{P}<0.0007)$ was on Ichinose $(0.45 \pm 0.20 \%$ and $3.28 \pm 0.04$, respectively). Also, the highest value of ECI $(\mathrm{F}=18.91 ; \mathrm{d}=3 ; \mathrm{P}<0.0005)(1.13 \pm 0.12 \%)$ was on Kenmochi compared with the other hosts. However, the larvae reared on Ichinose had the highest value of $\mathrm{AD}$ and the lowest value of $\mathrm{CI}(98.00 \pm 0.91$ and $3.28 \pm 0.04$, respectively). The highest and lowest value of $\mathrm{RGR}(\mathrm{F}=18.6$;

Table 1. Nutritional indices of second instar larvae of Glyphodes pyloalis on different hosts (means \pm SE).

\begin{tabular}{|c|c|c|c|c|c|}
\hline Host & CI & AD & ECI & ECD & RGR \\
\hline Ichinose & $3.28 \pm 0.04^{\mathrm{d}}$ & $98.00 \pm 0.91^{\mathrm{a}}$ & $0.44 \pm 0.20^{c}$ & $0.45 \pm 0.20^{c}$ & $0.02 \pm 0.00^{d}$ \\
\hline Shin Ichinose & $4.96 \pm 0.07^{c}$ & $97.50 \pm 0.27^{a}$ & $0.64 \pm 0.26 \mathrm{bc}$ & $0.66 \pm 0.03^{b c}$ & $0.03 \pm 0.00^{c}$ \\
\hline Kenmochi & $7.14 \pm 0.09^{a}$ & $97.60 \pm 0.25^{\mathrm{a}}$ & $1.13 \pm 0.12^{\mathrm{a}}$ & $1.15 \pm 0.12^{\mathrm{a}}$ & $0.05 \pm 0.01^{b}$ \\
\hline Mahalii & $5.85 \pm 2.02^{\mathrm{b}}$ & $96.99 \pm 0.72^{\mathrm{a}}$ & $0.82 \pm 0.27^{b}$ & $0.85 \pm 0.28^{\mathrm{ab}}$ & $0.07 \pm 0.00^{a}$ \\
\hline
\end{tabular}

$\mathrm{CI}$, consumption index; $\mathrm{AD}$, approximate digestibility; ECI, efficiency of conversion of ingested food; $\mathrm{ECD}$, efficiency of conversion of digested food; RGR, relative growth rate. a,b,c,dMeans followed by different letters in the same columns are significantly different (LSD, $\mathrm{P}<0.01)$.

Table 2. Nutritional indices of third instar larvae of Glyphodes pyloalis on different hosts (means \pm SE).

\begin{tabular}{lccccc} 
Host & CI & AD & BCI & ECD & RGR \\
Ichinose & $5.20 \pm 0.10^{\mathrm{c}}$ & $94.64 \pm 1.20^{\mathrm{a}}$ & $1.51 \pm 0.16^{\mathrm{a}}$ & $1.54 \pm 0.07^{\mathrm{a}}$ & $0.04 \pm 0.01^{\mathrm{b}}$ \\
Shin Ichinose & $4.83 \pm 0.60^{\mathrm{c}}$ & $91.69 \pm 0.89^{\mathrm{b}}$ & $1.32 \pm 0.12^{\mathrm{b}}$ & $1.45 \pm 0.13^{\mathrm{b}}$ & $0.17 \pm 0.02^{\mathrm{a}}$ \\
\hline Kenmochi & $9.23 \pm 0.40^{\mathrm{a}}$ & $95.12 \pm 0.55^{\mathrm{a}}$ & $0.98 \pm 0.22^{\mathrm{c}}$ & $1.05 \pm 0.24^{\mathrm{c}}$ & $0.06 \pm 0.02^{\mathrm{b}}$ \\
Mahalii & $7.88 \pm 0.6^{\mathrm{b}}$ & $94.60 \pm 0.50^{\mathrm{a}}$ & $1.55 \pm 0.12^{\mathrm{a}}$ & $1.64 \pm 0.13^{\mathrm{a}}$ & $0.08 \pm 0.01^{\mathrm{b}}$ \\
\hline
\end{tabular}

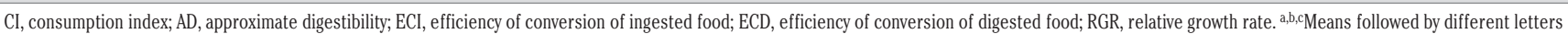
in the same columns are significantly different (LSD, $\mathrm{P}<0.01)$. 
$\mathrm{d}=3 ; \mathrm{P}<0.0003)$ were on Mahalii and Ichinose $(0.07 \pm 0.00$ and $0.02 \pm 0.00$, respectively) (Table 1$)$.

The highest $(95.12 \pm 0.55 \%)$ and lowest $(91.69 \pm 0.89 \%)$ AD values $(\mathrm{F}=10.51 ; \mathrm{df}=3 ; \mathrm{P}<0.0038)$ of the third instar larvae of $G$. pyloalis were on Kenmochi and Shin Ichinose, respectively. The Shin Ichinose and Ichinose showed the highest and lowest values of RGR $(\mathrm{F}=51.57 ; \mathrm{df}=3 ; \mathrm{P}<0.0001)(0.17 \pm 0.02$ and $0.04 \pm 0.01)$, respectively. The highest $(9.23 \pm 0.40 \%)$ and lowest $(4.83 \pm 0.60 \%)$ CI values $(\mathrm{F}=100.63 ; \mathrm{df}=3 ; \mathrm{P}<0.0001)$ were on Kenmochi and Shin Ichinose, respectively (Table 2 ).

In the fourth instar, the highest $(95.23 \pm 0.74)$ and lowest $(91.77 \pm 1.46)$ values of $\mathrm{AD}(\mathrm{F}=6.71 ; \mathrm{df}=3 ; \mathrm{P}<0.0141)$ were on Kenmochi and Shin Ichinise. The larvae fed on Shin Ichinose had the highest ECI $(\mathrm{F}=9.58 ; \mathrm{df}=3 ; \mathrm{P}<0.005)$ and $\mathrm{ECD}(\mathrm{F}=16.69 ; \mathrm{df}=3 ; \mathrm{P}<0.0001)$ values $(0.80 \pm 0.06$ and $0.97 \pm 0.21$, respectively). However, the lowest value of ECI and ECD $(0.40 \pm 0.03$ and, $0.41 \pm 0.03$ respectively) was observed on Kenmochi (Table 3).

It was observed that larvae fed on Kenmochi in the fifth instar had the highest $\mathrm{CI}(\mathrm{F}=26.84 ; \mathrm{df}=3 ; \mathrm{P}<0.0002)$ and $\mathrm{AD}(\mathrm{F}=0.35 ; \mathrm{df}=3$; $\mathrm{P}<0.7885)$ values $(4.60 \pm 0.73$ and $89.22 \pm 5.60$, respectively) and the larvae that fed on Mahalii had the lowest values of CI and AD $(1.86 \pm 0.06$ and 77.54 \pm 5.63$)$. The highest and lowest RGR values $(\mathrm{F}=29.67 ; \mathrm{df}=3$; $\mathrm{P}<0.0001)$ were observed on Mahalii and Kenmochi $(0.10 \pm 0.00$ and $0.04 \pm 0.10$, respectively) (Table 4$)$.

In most cases, the highest and lowest values of $\mathrm{AD}(\mathrm{F}=7.48 ; \mathrm{df}=2$, $116 ; \mathrm{P}<0.01)$ were on the second and fifth instars, respectively. The highest and lowest values of ECI $(\mathrm{F}=8.75 ; \mathrm{df}=2,114 ; \mathrm{P}<0.01)$ and $\mathrm{ECD}$ $(\mathrm{F}=15.56 ; \mathrm{df}=2,113 ; \mathrm{P}<0.01)$ were on the fifth and fourth instars, respectively.

\section{Biochemical assessments}

The results of biochemical assessments of $G$. pyloalis larvae fed on different host are shown in Table 5. The larvae reared on Mahalii $(0.97 \pm 0.02 \mathrm{U} / \mathrm{mg})$ showed the highest levels of proteolytic activity. However, protease activity was the lowest in midgut extracts from larvae fed on Kenmochi $(0.75 \pm 0.03 \mathrm{U} / \mathrm{mg})(\mathrm{F}=6.86$, $\mathrm{df}=3, \mathrm{P}<0.0013$ ).

It was observed that larvae fed on Mahalii had the highest activity of trypsin $(\mathrm{F}=26.8, \mathrm{df}=3, \mathrm{P}<0.0001)$ and elastase $(\mathrm{F}=58.86, \mathrm{df}=3$, $\mathrm{P}<0.008),(2.30 \pm 0.0$ and $2.13 \pm 0.00 \mathrm{U} / \mathrm{mg}$, respectively) and the larvae that fed on Kenmochi had the lowest activity of trypsin and elastase $(0.54 \pm 0.00$ and $1.36 \pm 0.02 \mathrm{U} / \mathrm{mg}$, respectively). The larvae reared on Kenmochi $(1.31 \pm 0.01 \mathrm{U} / \mathrm{mg})$ showed the highest activity of chymotrypsin $(\mathrm{F}=6.35, \mathrm{df}=3, \mathrm{P}<0.003)$.

As for proteolytic activity, the highest levels of amylase activity ( $\mathrm{F}=1.51, \mathrm{df}=3, \mathrm{P}<0.0028$ ) were found on the larvae that fed on Mahalii $(0.17 \pm 0.10 \mathrm{U} / \mathrm{mg})$.

As illustrated in Table 5 , the highest activity level of ALT ( $\mathrm{F}=59.27$, $\mathrm{df}=3, \mathrm{P}<0.0001)$ and AST $(\mathrm{F}=3.59, \mathrm{df}=3, \mathrm{P}<0.006)$ were found on Shin Ichinose $(8.92 \pm 0.69$ and $15.65 \pm 2.44 \mathrm{U} / \mathrm{mg}$, respectively) and the lowest on Kenmochi. The larvae that fed on Mahalii had the highest ALP $(\mathrm{F}=3.55, \mathrm{df}=3, \mathrm{P}<0.006)$ and ACP $(\mathrm{F}=8.49, \mathrm{df}=3, \mathrm{P}<0.003)$ values $(0.09 \pm 0.05$ and $0.11 \pm 0.07 \mathrm{U} / \mathrm{mg}$, respectively) and were lowest on Ichinose $(0.02 \pm 0.01$ and $0.04 \pm 0.01$, respectively).

The highest total protein was observed on Mahalii, while the lowest was on Kenmochi $(1.19 \pm 0.20,0.89 \pm 0.12$, respectively) ( $\mathrm{F}=4.39$, $\mathrm{df}=3, \mathrm{P}<0.0019$ ).

It was observed that larvae fed on Mahalii had the highest trehalose $(\mathrm{F}=3.43, \mathrm{df}=3, \mathrm{P}<0.003)$ and cholesterol $(\mathrm{F}=0.49, \mathrm{df}=3$, $\mathrm{P}<0.0009)$ values $[21.14 \pm 2.53(\mathrm{mg} / \mathrm{dL})$ and $0.08 \pm 0.04(\mathrm{mg} / \mathrm{dL})$ respectively], and larvae reared on Shin Ichinose showed the highest level of glucose $(\mathrm{F}=10.45, \mathrm{df}=3, \mathrm{P}<0.003) 0.98 \pm 0.02(\mathrm{mg} / \mathrm{dL})$ (Table 5).

\section{Chemical analyses of the leaves}

The results of leaf analysis demonstrated that phosphorus content was highest in Shin Ichinose and lowest in Ichinose $(0.34 \pm 0.02$ and $0.24 \pm 0.01$ ), respectively. The other two varieties were not significantly different from each other $(\mathrm{F}=6.57 ; \mathrm{df}=3 ; \mathrm{P}>0.0150)$. Potassium content was not significantly different among the varieties $(\mathrm{F}=2.76 ; \mathrm{df}=3 ; \mathrm{P}>0.1113)$, while the highest nitrogen content was observed in Mahalii $(3.07 \pm 0.24)$ and the lowest in Kenmochi $(2.07 \pm 0.68)(\mathrm{F}=5.88 ; \mathrm{df}=3 ; \mathrm{P}>0.0202)$. Similarly, protein content was highest in Mahalii and lowest in Kenmochi (19.18 \pm 0.52 and $12.93 \pm 2.67$, respectively). However, calcium content was highest in Shin Ichinose and Kenmochi and lowest in Mahalii and Ichinose $(\mathrm{F}=8.03 ; \mathrm{df}=3 ; \mathrm{P}>0.0085)$ (Table 6).

Table 3. Nutritional indices of fourth instar larvae of Glyphodes pyloalis on different hosts (means \pm SE).

\begin{tabular}{|c|c|c|c|c|c|}
\hline Host & CI & AD & ECI & $\mathrm{ECD}$ & RGR \\
\hline Ichinose & $2.60 \pm 0.22^{\mathrm{bc}}$ & $92.53 \pm 0.59^{b}$ & $0.76 \pm 0.25^{\mathrm{a}}$ & $0.79 \pm 0.21^{a b}$ & $0.03 \pm 0.04^{\mathrm{b}}$ \\
\hline Shin Ichinose & $2.23 \pm 0.18^{c}$ & $91.77 \pm 1.46^{b}$ & $0.80 \pm 0.06^{a}$ & $0.97 \pm 0.21^{\mathrm{a}}$ & $0.02 \pm 0.00^{b}$ \\
\hline Kenmochi & $4.62 \pm 0.10^{\mathrm{a}}$ & $95.23 \pm 0.74^{\mathrm{a}}$ & $0.40 \pm 0.03^{b}$ & $0.41 \pm 0.03^{b}$ & $0.02 \pm 0.01^{b}$ \\
\hline Mahalii & $2.93 \pm 0.05^{b}$ & $91.90 \pm 1.29^{b}$ & $0.58 \pm 0.33^{\mathrm{ab}}$ & $0.63 \pm 0.37^{a b}$ & $0.06 \pm 0.02^{a}$ \\
\hline
\end{tabular}

$\mathrm{Cl}$, consumption index; $\mathrm{AD}$, approximate digestibility; ECI, efficiency of conversion of ingested food; $\mathrm{ECD}$, efficiency of conversion of digested food; RGR, relative growth rate. ${ }^{\text {ab,c }}$ Means followed by different letters in the same columns are significantly different (LSD, $\mathrm{P}<0.01)$.

Table 4. Nutritional indices of fifth instar larvae of Glyphodes pyloalis on different hosts (means \pm SE).

\begin{tabular}{lccccc} 
Host & CI & AD & ECI & BCD & RGR \\
Ichinose & $3.14 \pm 0.2^{\mathrm{b}}$ & $81.80 \pm 3.89^{\mathrm{ab}}$ & $2.64 \pm 0.13^{\mathrm{ab}}$ & $2.82 \pm 0.24^{\mathrm{b}}$ & $0.05 \pm 0.01^{\mathrm{bc}}$ \\
Shin Ichinose & $2.34 \pm 0.19^{\mathrm{bc}}$ & $81.98 \pm 0.52^{\mathrm{ab}}$ & $3.10 \pm 0.09^{\mathrm{a}}$ & $3.82 \pm 0.16^{\mathrm{a}}$ & $0.06 \pm 0.01^{\mathrm{b}}$ \\
\hline Kenmochi & $4.60 \pm 0.73^{\mathrm{a}}$ & $89.22 \pm 5.60^{\mathrm{a}}$ & $2.23 \pm 0.36^{\mathrm{b}}$ & $2.81 \pm 0.50^{\mathrm{b}}$ & $0.04 \pm 0.10^{\mathrm{c}}$ \\
Mahalii & $1.86 \pm 0.06^{\mathrm{c}}$ & $77.54 \pm 5.63^{\mathrm{b}}$ & $2.68 \pm 0.15^{\mathrm{ab}}$ & $3.20 \pm 0.29^{\mathrm{ab}}$ & $0.10 \pm 0.00^{\mathrm{a}}$ \\
\hline
\end{tabular}

$\mathrm{CI}$, consumption index; $\mathrm{AD}$, approximate digestibility; ECI, efficiency of conversion of ingested food; ECD, efficiency of conversion of digested food; RGR, relative growth rate. a,b,cMeans followed by different letters in the same columns are significantly different (LSD, $\mathrm{P}<0.01)$. 


\section{Discussion and conclusions}

The use of resistant varieties is one of the core strategies of an integrated pest management program, and secondary substances of plants or allelochemicals play a major role in plant resistance to pests (Wilson \& Huffaker, 1976). Differences in allelochemical concentrations between host plant varieties can affect an insect's performance as a larva (Martin \& Pulin, 2004).

It is generally accepted that low dietary protein can cause an increase in the rate at which larvae feed (Rausher, 1981; Slansky, 1993); conversely, a high protein diet can reduce feeding rates (Mattson, 1980). In our study, the highest level of protein was recorded in leaves of the variety Mahalii. However, the lowest CI was recorded in fifth instar G. pyloalis larvae fed on Mahalii leaves. Also, the highest CI was observed on the variety Kenmochi, which had the lowest leaf protein content. Hemati et al. (2011) recorded that $H$. armigera larvae had the highest CI values when they were fed on tomato leaves, for which Kotkar et al. (2009) reported very low protein content.

Significant differences were found within the nutritional indices, especially ECI and ECD values, of $G$. pyloalis reared on different mulberry varieties, suggesting that the varieties have different nutritional value. Among nutritional indices, ECI may vary with the digestibility of food and the proportional amount of the digestible portion of food that is converted to body mass and metabolized for energy needed for vital activity (Abdel-Rahman \& Al-Mozini, 2007). ECI is the insect's ability to utilize the food ingested for growth and development, and ECD is a measure of the efficiency of conversion of digested food into growth
(Senthil-Nathan et al., 2005). Change in ECD also indicates the overall increase or decrease of the proportion of digested food metabolized for energy (Koul et al., 2004).

For the fifth larval instars, the highest ECI and ECD values were on Shin Ichinose, suggesting that the larvae were more efficient at conversion of ingested and digested food to body biomass with a high increase in larval weight. Despite Kenmochi's having the highest CI value, it also had the lowest values of ECI and ECD (Table 4), indicating that larvae feeding on this host were less effective in converting ingested and digested food into biomass. It is well known that the degree of food utilization depends on the digestibility of food, and the efficiency with which digested food is converted into biomass (Batista Pereira et al., 2002). The reduction in dietary utilization suggests that reduction in nutritional values may be a result of both behavioural and physiological effects (Senthil-Nathan et al., 2005).

Approximate digestibility (AD) and efficiency of conversion of digested food (ECD) are inversely related (Waldbauer, 1968; Scriber \& Slansky, 1981) and this is demonstrated in larvae reared on Kenmochi, which had the highest rate of $\mathrm{AD}$ and lowest rate of ECD.

Reduced RGR due to decreased ECD, despite an observed increase in $\mathrm{AD}$, was noticed in larvae of $4^{\text {th }}$ and $5^{\text {th }}$ instar reared on the variety Kenmochi. Growth reduction in response to a new environment (host) has been previously shown in phytophagous insects (Grabstein \& Scriber, 1982; Sheppard \& Friedman, 1990; Lazarevic \& PericMataruga, 2003).

Lepidopteran larvae fed on high-nutrient food have increased growth rates and a shorter developmental period than larvae fed on lownutrient food (Hwang et al., 2008). Our results showed that RGR values

Table 5. Comparison of biochemical compounds of Glyphodes pyloalis on four varieties of mulberry.

\begin{tabular}{lcccc} 
Compounds & Ichinose & Shin Ichinose & Kenmochi & Mahalii \\
$\alpha$-amylase (U/mg) & $0.11 \pm 0.01^{\mathrm{b}}$ & $0.10 \pm 0.05^{\mathrm{b}}$ & $0.10 \pm 0.05^{\mathrm{b}}$ & $0.17 \pm 0.10^{\mathrm{a}}$ \\
Ptotease (U/mg) & $0.89 \pm 0.01^{\mathrm{a}}$ & $0.80 \pm 0.04^{\mathrm{ab}}$ & $0.75 \pm 0.03^{\mathrm{b}}$ & $0.97 \pm 0.02^{\mathrm{a}}$ \\
\hline Trypsin (U/mg) & $2.14 \pm 0.00^{\mathrm{b}}$ & $1.91 \pm 0.01^{\mathrm{c}}$ & $0.54 \pm 0.00^{\mathrm{d}}$ & $2.30 \pm 0.02^{\mathrm{a}}$ \\
Chymotrypsin (U/mg) & $0.66 \pm 0.02^{\mathrm{b}}$ & $0.83 \pm 0.01^{\mathrm{b}}$ & $1.31 \pm 0.01^{\mathrm{a}}$ & $0.65 \pm 0.01^{\mathrm{b}}$ \\
\hline Elastase (U/mg) & $1.75 \pm 0.01^{\mathrm{b}}$ & $1.86 \pm 0.03^{\mathrm{a}}$ & $1.36 \pm 0.02^{\mathrm{c}}$ & $2.13 \pm 0.00^{\mathrm{a}}$ \\
Protein (mg/dL) & $0.97 \pm 0.04^{\mathrm{ab}}$ & $1.03 \pm 0.02^{\mathrm{ab}}$ & $0.89 \pm 0.12^{\mathrm{b}}$ & $1.19 \pm 0.20^{\mathrm{a}}$ \\
\hline Glucose (mg/dL) & $0.80 \pm 0.01^{\mathrm{b}}$ & $0.98 \pm 0.02^{\mathrm{a}}$ & $0.92 \pm 0.08^{\mathrm{a}}$ & $0.95 \pm 0.01^{\mathrm{a}}$ \\
Cholesterol (mg/dL) & $0.01 \pm 0.00^{\mathrm{b}}$ & $0.02 \pm 0.01^{\mathrm{b}}$ & $0.02 \pm 0.01^{\mathrm{b}}$ & $0.08 \pm 0.04^{\mathrm{a}}$ \\
\hline Glycogen (mg/dL) & $0.02 \pm 0.00^{\mathrm{a}}$ & $0.02 \pm 0.00^{\mathrm{a}}$ & $0.02 \pm 0.00^{\mathrm{a}}$ & $0.02 \pm 0.00^{\mathrm{a}}$ \\
Trehalose (mg/dL) & $12.86 \pm 2.63^{\mathrm{c}}$ & $18.45 \pm 0.66^{\mathrm{ab}}$ & $17.53 \pm 5.57^{\mathrm{b}}$ & $21.14 \pm 2.53^{\mathrm{a}}$ \\
\hline Alkalinaminoteransferase (IU/L) & $6.60 \pm 0.66^{\mathrm{b}}$ & $8.92 \pm 0.69^{\mathrm{a}}$ & $2.99 \pm 0.47^{\mathrm{c}}$ & $6.03 \pm 0.27^{\mathrm{b}}$ \\
Aspartate aminoteransferase (IU/L) & $13.35 \pm 2.57^{\mathrm{a}}$ & $15.65 \pm 2.44^{\mathrm{a}}$ & $3.99 \pm 0.58^{\mathrm{b}}$ & $6.95 \pm 1.59^{\mathrm{b}}$ \\
\hline Alkaline phosphatase (IU/L) & $0.04 \pm 0.01^{\mathrm{b}}$ & $0.04 \pm 0.01^{\mathrm{b}}$ & $0.05 \pm 0.02^{\mathrm{b}}$ & $0.09 \pm 0.05^{\mathrm{a}}$ \\
Acids phosphatase (IU/L) & $0.02 \pm 0.01^{\mathrm{b}}$ & $0.02 \pm 0.01^{\mathrm{b}}$ & $0.04 \pm 0.01^{\mathrm{b}}$ & $0.11 \pm 0.07^{\mathrm{a}}$ \\
\hline
\end{tabular}

a,b,c,dMeans followed by different letters in the same columns are significantly different $(\mathrm{LSD}, \mathrm{P}<0.01)$.

Table 6. Chemical analyses of leaves of four different varieties of mulberry (means $\pm S E$; ingredient \%D.M.).

\begin{tabular}{|c|c|c|c|c|c|}
\hline Host & $\mathbf{P}$ & $\mathbf{K}$ & $\mathbf{N}$ & $\mathrm{Ca}$ & Protein \\
\hline Ichinose & $0.24 \pm 0.01^{b}$ & $2.31 \pm 0.05^{\mathrm{a}}$ & $2.62 \pm 0.11^{\mathrm{ab}}$ & $2.59 \pm 1.14^{\mathrm{b}}$ & $16.37 \pm 0.72^{a b}$ \\
\hline Shin Ichinose & $0.34 \pm 0.02^{a}$ & $2.44 \pm 0.02^{\mathrm{a}}$ & $2.76 \pm 0.61^{\mathrm{ab}}$ & $3.22 \pm 0.22^{\mathrm{a}}$ & $17.25 \pm 1.60^{a b}$ \\
\hline Kenmochi & $0.32 \pm 0.01^{\mathrm{ab}}$ & $2.42 \pm 0.04^{\mathrm{a}}$ & $2.07 \pm 0.68^{b}$ & $3.16 \pm 0.17^{\mathrm{a}}$ & $12.93 \pm 2.67^{\mathrm{b}}$ \\
\hline Mahalii & $0.32 \pm 0.16^{\mathrm{ab}}$ & $2.47 \pm 0.39^{a}$ & $3.07 \pm 0.24^{\mathrm{a}}$ & $2.59 \pm 0.48^{b}$ & $19.18 \pm 0.52^{\mathrm{a}}$ \\
\hline
\end{tabular}

a,bMeans followed by different letters in the same columns are significantly different $(\mathrm{LSD}, \mathrm{P}<0.01)$. 
were highest on Mahalii and lowest on Kenmochi, indicating that Kenmochi was a low-nutrient food for larvae, and a longer period of development was therefore needed by the immature stages. Conversely, the Mahalii plants were high-nutrient foods for larvae, and a shorter period of development was needed by the immature stages.

The data on nutritional indices for the fourth and fifth instars of $G$. pyloalis are not consistent. This is because the nutritional requirements of the insect change through development, and such differences typically result in changes in food consumption and feeding behavior (Barton Browme, 1995). Analysis of nutritional indices can lead to an understanding of the behavioural and physiological bases of insect response to host plants (Lazarevic \& Peric-Mataruga, 2003). The lower fitness of $G$. pyloalis on some hosts may be due to the presence of some secondary phytochemicals in these hosts, or the absence of primary nutrients necessary for growth and development. To obtain more applicable information for $G$. pyloalis control, more attention should be devoted to studying the demographic parameters of this pest under laboratory and field conditions, as well as to investigate its nutritional indices on different varieties of mulberry under field conditions.

Isolation and study of distinct proteases and amylases is of little aid in ascertaining the composition of the midgut or designing PI-based approaches for insect resistance, especially when the insect has the ability to modify midgut compounds within a single generation in order to deactivate the influence of PIs (Patankar et al., 2001; Vinokurov et al., 2007). Insects adjust to plant PIs by producing inhibitor-insensitive, inhibitor-resistant and inhibitor-declining proteinases in their midgut to compensate for the influence of transgenic or dietary PIs (Jongsma et al., 1995; Broadway, 1997; Michaud, 1997; Girard et al., 1998; Giri \& Kachole, 1998). Therefore, determination of the midgut protease and amylase activities induced upon intake of PIs will be essential for selecting PIs or a mixture of PIs for expanding insect resistance (Patankar et al., 2001). In the current research, higher protease activities in the Mahalii-fed larvae may have been due to the high protein content of the diet or to the response of the insect to the dietary PIs that partially inhibit midgut protease activity (Patankar et al., 2001).

Additionally, hyperproduction of proteases in response to ingested PIs leads to an extra load on the insect for energy and essential amino acids, resulting in a retardation of insect growth (Broadway \& Duffy, 1986).

The highest trypsin- and elastase-like activities were also in Mahalii-fed larvae compared with the other varieties, and proteases and trypsin activity in the larvae reared on Kenmochi and Shin Ichinose were lowest. Lectins are carbohydrate-binding proteins distributed in different species of plants (Etler, 1986; Ratanapo, 2005). They play different roles in plants; many of them have a direct inhibitory effect on some digestive enzymes of higher animals and insects, including $\alpha$-amylases (Thompson \& Gabon, 1986; Fish \& Thompson, 1991), and esterases and proteases (Belzunces et al., 1994; Thompson et al., 1986). Ratanapo et al. (2005) reported two mulberry leaf lectins, MLL1 and MLL2, that have an inhibitory effect on trypsin-like alkaline proteases purified from the digestive fluid of the fifth larval instar of the silkworm, Bombyx mori. Anti-proteolytic effect of lectins on the digestive proteases might occur prior to silkworm digestion of food protein. In this research, lower activity of protease and trypsin in Shin Ichinose than in Ichinose may indicate the existence of lectin/s in this variety. However, the larvae fed on Kenmochi exhibited the highest chymotrypsin activity compared with other varieties. The tentative answer to this phenomenon could be the over-expression of chymotrypsin-like enzymes in response to the trypsin inhibitors in this variety. Trypsin and chymotrypsin occur as multiple isoforms in insects (Lam et al., 1999, 2000; Lopes et al., 2006; Sato et al., 2008).

The highest levels of amylase activity were found on the larvae that fed on Mahalii. The reason could be that this host had the highest balance of carbohydrates. According to chemical analyses of leaves, we observed that the varieties Mahalii and Kenmochi had the highest and lowest levels of protein, respectively. Hemati et al. (2011) showed that the larvae reared on the tomato cultivar Dehghan had the highest level of proteolytic and amylolytic activity.

The aminotransferases are enzymes that catalyze the reaction between an amino acid and a keto acid. This reaction removes the amino group from the amino acid, leaving a keto acid and converting it into an amino acid. These enzymes serve as a link between the carbohydrates and protein metabolism and are altered during various physiological processes (Etebari et al., 2004; Shekari et al., 2008). Our results show that Shin Ichinose and Kenmochi had the highest and lowest level of ALT and AST, respectively. The reason may be that Kenmochi had the lowest balance of protein. ACP and ALP are the hydrolase enzyme responsible for removing phosphate groups from many types of molecules, including nucleotides, proteins, and alkaloids in alkaline and acidic conditions, both of which were highest in Mahalii. According to the results of chemical analyses of the leaves, Mahalii leaves indeed had the highest level of protein (Table 6).

Glycogen is a polymer of several glucose residues in a branched chain storage form (Klowden, 2007; Lide, 1998); both glucose and glycogen were highest in the larvae that were reared on Shin Ichinose.

In this research, we observed that the larvae that were reared on Mahalii and Kenmochi had the highest and lowest total protein, respectively, which corresponds with other results showing that these varieties have the highest and lowest protein contents.

In this study, we found that the chemical compounds present in the host plant can play an important role in the feeding activity, digestive enzyme activity and chemical compounds stored in the plant when fed upon by pests. Based on our results, the variety Mahalii had the highest nutritional indices and the highest activity of digestive enzymes to make it the best host for $G$. pyloalis. The variety Kenmochi had the lowest activity of digestive enzymes and nutritional indices, identifying it as an unsuitable host.

The low activity of digestive enzymes and nutritional indices of $G$. pyloalis on Kenmochi could possibly indicate the presence of some enzyme inhibitors in this variety. However, the suitability of the Mahalii and Shin Ichinose varieties could be due to the protein content and nutritional value of these hosts in comparison to other hosts in this study.

The inappropriateness of some of the hosts for $G$. pyloalis may be due to some chemical secondary compounds in the hosts, or absence of an essential nutrient for the growth of $G$. pyloalis.

\section{References}

ABDEL-RAHMAN H.R., AL-MOZINI R.N., 2007 - Antifeedant and toxic activity of some plant extracts against larvae of cotton leafworm Spodoptera littoralis (Lepidoptera: Noctuidae). -Pak. J. Biol. Sci. 10: 4467-4472.

ARUGA H., 1994 - Principles of Sericulture, 1st ed. - CRC Press, Boca Raton, FL: 79-80.

BARTON BROWME L., 1995 - Ontogenetic changes in feeding behavior. In: CHAPMAN R.F., De BOER G. (Eds.), Regulatory mechanisms in insect feeding. - Chapman and Hall, New York: 307-342.

BARTON BROWME L.B., RAUBENHEIMER D., 2003 - Ontogenetic changes in the rate of ingestion and estimates of food consumption in fourth and fifth instar Helicoverpa armigera caterpillars. -J. Insect Physiol. 49: 63-71.

BATISTA PEREIRA G.L., PETACCI F., FERNANDES B.J., CORREA A.G., VIEIRA P.C., FATIMA D.A., SILVA M., MALASPINA 0., 2002 Biological activity of astilbin from Dimorphandra mollis against Anticarsia gemmatalis and Spodoptera frugiperda. - Pest Manag. Sci. 58: 503-507.

BELZUNCES L.P., CHRISTOPHE L., PASQUALE S.D.I., COLIN M.E., 1994 
- In vivo and in vitro effects of wheat germ agglutinin and BowmaBirk soybean trypsin inhibitor, two potential transgene products, on midgut esterase and protease activities from Apis mellifera. Comp Biochem. - Physiol. 109B: 63-69.

BERNFELD P., 1955 - a-Amylases. - Method Enzymol. - 1: 149-151.

BESSEY O.A., LOWRY 0.H., BROCK M.J., 1946 - A method for the rapid determination of alkaline phosphatase with five cubic millimeters of serum. - Biochem. J. 164: 321-329.

BOWN D.P., WILKINSON H.S., GATEHOUSE J.A., 1997 - Differentially regulated inhibitor-sensitive and insensitive protease genes from the phytophagous insect pest Helicoverpa armigera, are members of complex multi gene families. - Insect Biochem. Mol. Biol. 27: 625-638.

BRADFORD M.M., 1976 - A rapid and sensitive method for the quantitation of microgram quantities of protein utilizing the principle of protein dye binding. - Analyt. Biochem.72: 248.

BROADWAY R.M., 1997 - Dietary regulation of serine proteinases that are resistant to serine proteinase inhibitors. - J. Insect. Physiol. 43: 855-874.

BROADWAY R.M., DUFFY S.S., 1986 - Plant proteinase inhibitors: mechanism of action and effect on the growth and digestive physiology of larval Heliothis zea and Spodoptera exigua. - J. Insect Physiol. 32: 827-833.

DAVID W.A.L., GARDINER B.O.C., 1962 - Observation on the larva and pupa of Pieris brassicae L. in the laboratory culture. - Bull. Entomol. Res. 53: 414-436.

DAVIDSON C.B., JOHNSON J.E., GOTTSCHALK K.W., AMATEIS R.L., 2001 - Prediction of stand susceptibility and gypsy moth defoliation in coastal plain mixed pine- hardwoods. - Can. J. Forest Res. 31: 1914-1921.

ETEBARI K., MATINDOOST L., 2004 - A study on the effects of larval age on biochemical macromolecules abundance of haemolymph in silkworm Bombyx mori L. (Lepidoptera: Bombycidae). - J. Entomol. Soc. Iran 24: 1-16.

ETLER M.E., 1986 - Distribution and function of plant lectins. In: E.E LIENER, N. SHARON, I.J. GOLDSTEIN (Eds.), Lectins: properties, function and application in biology and medicine. - Academic Press, London/Orlando: 371-435.

FISH B.C., THOMPSON L.U., 1991 - Lectin tannin interactions and their influence on pancreatic amylase activity and starch digestibility. J. Agric. Food Chem. 39: 727-731.

FOSS L.K., RIESKE L.K., 2003 - Species-specific differences in oak foliage affect preference and performance of gypsy moth caterpillar. - Entom. Exp. Appl. 108:87-93.

FRANCO O.L., RIGDEN D.J., MELO F.R., BLOCH Jr. C., SILVA C.P., GROSSI-DE-SA, M. F., 2000 -Activity of wheat $\alpha$-amylase inhibitors towards bruchid $\alpha$-amylases and structural explanation of observed specificities. - Eur. J. Biochem. 267: 2166-2173.

FRANCO 0.L., RIGDEN, D.J., MELO F.R., GROSSI-DE-SA M.F., 2002 Plant alpha amylase inhibitors and their interaction with insect alpha amylases structure, function and potential for crop protection. - Eur. J. Biochem. 269: 397-412.

GIRARD C., LE METAYER M., BONADE-BOTTINO M., PHAM-DELEGUE M.H., JOUANIN L., 1998 - High level of resistance to proteinase inhibitors may be conferred by proteolytic cleavage in beetle larvae. - J. Insect. Biochem. Physiol. 28: 229-237.

GIRI A.P., KACHOLE M.V., 1998 - Amylase inhibitors of pigeon pea (Cajanus cajan) seeds. - Phytochemistry 47: 197-202.

GRABSTEIN E.M., SCRIBER J.M., 1982 - Host-plant utilization by Hyalophora cecropia as affected by prior feeding experience. Entomol. Exp. Appl. 32: 262-268.

HEMATI S.A., NASERI B., NOURI GANBALANIC G., RAFIEE DASTJERDI H., GOLIZADEH A., 2011 - Effect of different host plants on nutritional indices of the pod borer, Helicoverpa armigera. - J. Insect Sci. 12: 55.
HILDER V.A., GATEHOUSE A.M.R., SHEERMAN S.E., BARKER R.F., BOULTER D., 1987 - A novel mechanism of insect resistance engineered into tobacco. - Nature 330: 160-165.

HOSSEININAVEH V., BANDANI A., AZMAYESHFARD P., HOSSEINKHANI S., KAZEMI M., 2007 - Digestive proteolytic and amylolytic activities in Trogoderma granarium Everts (Dermestidae: Coleoptera). - J. Stored Prod. Res. 43: 515-522.

HWANG S.Y., LIU C.H., SHEN T.C., 2008 - Effects of plant nutrient availability and host plant species on the performance of two Pieris butterflies (Lepidoptera: Pieridae). - Biochem. Sys. Ecol. 36:505-513.

JOHNSTON K.A., GATEHOUSE J.A., ANSTEE J.H., 1993 - Effects of soybean trypsin inhibitors on the growth and development of larval Helicoverpa armigera. - J. Insect Physiol. 39: 657-664.

JONGSMA M.A., BAKKER P.L., PETERS J., BOSCH D., STIEKEMA W.J., 1995 - Adaptation of Spodoptera exigua larvae to plant proteinase inhibitors by induction of gut proteinase activity insensitive to inhibition. - Proc. Natl. Acad. Sci. U. S. A. 92: 8041-8045.

KHOSRAVI R., SENDI J.J., 2010 - Biology and demography of Glyphodes pyloalis Walker (Lepidoptera: Pyralidae) on mulberry. - J.AsiaPacific. Entomol. 13: 273-276.

KLOWDEN M.J., 2007 - Physiological systems in insects. - Academic Press, New York: 697.

KOTKAR H.M., SARATE P.J., TAMHANE V.A., GUPTA V.S., GIRI A.P., 2009 - Responses of midgut amylases of Helicoverpa armigera to feeding on various host plants. - J. Insect. Physiol. 55: 663-670.

KOUL 0., SINGH G., SING R., SINGH J., 2004 - Bioefficacy and mode-ofaction some limonoids of salanin group from Azadirachta indica A. Juss and their role in a multicomponent system against lepidopteran larvae. - J. Biosci. 29: 409-416.

KUMAR V., KUMAR V., RAJADURAI S., BABU A.M., KATIYAR R.L., KARIAPPA B.K., THIAGARAJAN V., JAYASWAL K.P., 2002 - The chronic architecture and shell structure of Diaphania pulverulentalis (Hampson) (Lepidoptera: Pyralidae). - Russ. Entomol. J. 11: 307-310.

LAM W., COAST G.M., RAYNE C., 1999 - Isolation and characterisation of two chymotrypsins from the midgut of Locusta migratoria. Insect Biochem. Mol. Biol. 29: 653-660.

LAM W., COAST G.M., RAYNE C., 2000 - Characterisation of multiple trypsins from the midgut of Locusta migratoria. - Insect Biochem. Mol. Biol.30: 85-94.

LAWRENCE P.K.Y.I., KOUNDAL K.R., 2002 - Plant protease inhibitors in control of phytophagous insects. - Electronic. J. Biotechnol. 5: 1-17.

LAZAREVIC J., PERIC-MATARUGA V., 2003 - Nutritive stress effects on growth and digestive physiology of Lymantria dispar larvae. - Yug. Med. Biochem. 22: 53-59.

LEWIS W.J., VAN LETEREN J.C., PHATAK S.C., TUMLINSON J.H., 1997 A total system approach to sustainable pest management. - Proc. Natl. Acad. Sci. U. S. A. 94: 12243-12248.

LI Y., HILL C.B., HARTMAN G.L., 2004 - Effect of three resistant soybean genotypes on the fecundity, mortality and maturation of soybean aphid (Homoptera, Aphididae). - J. Econ. Entomol. 97: 1106-1111.

LIDE D.R., 1998 - Handbook of chemistry and physics, 87 ed. - CRC Press, Boca Raton, FL: 3-534.

LOPES A.R., JULIANO M.A., MARANA S.R., JULIANO L., TERRA W.R., 2006 - Substrate specificity of insect trypsins and the role of their subsites in catalysis. - Insect Biochem. Mol. Biol. 36: 130-140.

MADYAROV Sh. R., KHAMRAEV A. Sh., OTARBAEV D.0., KAMITA S.G., HAMMOCK B.D., 2006 - Comparative effects of wild and recombinant baculoviral insecticides on mp glyphodes pyloalis wlk. and mulberry silkworm bombyx moryl. International Workshop on Silk Handcrafts Cottage Industries and Silk Enterprises Development in Africa, Europe, Central Asia and the Near East, \& Second Executive Meeting of Black, Caspian seas and Central Asia Silk Association (BACSA) Bursa, Turkey.

MARTIN L.A., PULIN A.S., 2004 - Host-plant specialization and habitat 
restriction in an endangered insect, Lycaena dispar batavus (Lepidoptera: Lycaenidae) I. Larval feeding and oviposition preferences. - Eur. J. Entomol. 101: 51-56.

MATTSON JR W.J., 1980 - Herbivory in relation to plant nitrogen content. - Ann. Rev. Ecol. Sys. 11: 119-161.

MENDIOLA-OLAYA E., VALENCIA-JIMENEZ A., VALDES-RODRIGUEZ S., DELANO-FRIER J., BLANCO-LABRA A., 2000 - Digestive amylase from the larger grain borer, Prostephanus truncatus Horn. - Comp. Biochem. Physiol. B. 126: 425-433.

MEYER G.A., MONTGOMERY M.E., 2004 - Relationship between leaf age and the food quality of Cottonwood foliage for the Gypsy Moth, Lymantria dispar. - Oecologia 72: 527-532.

MICHAUD D., 1997 - Avoiding protease-mediated resistance in herbivorous pests. - Trends Biotechnol. 15: 4-6.

PATANKAR A.G., GIRI A.P., HARSULKAR A.M., SAINANI M.N., DESHPANDE V.V., RANJEKAR P.K., GUPTA V.S., 2001 - Complexity in specificities and expression of Helicoverpa armigera gut proteases explains polyphagous nature of the insect pest. - Insect Biochem. Molec. Biol. 31: 453-464.

PEREIRA P.J.B., LOZANOV V., PATTHY A., HUBER R., BODE W., PONGOR S., STROBL S., 1999 - Specific inhibition of insect amylases: yellow mealworm $\alpha$-amylase in complex with the Amaranth $\alpha$ amylases inhibitor at 2.0A resolution. - Structure. 9: 1079-1088.

RATANAPO S., THAWALVICHIT Y., PROMBOON A., 2005 - Inhibitory Effects of mulberry leaf lectins to silkworm proteases. - J. Nat. Sci.39: 125-135.

RAUSHER M.D., 1981 - Host-plant selection by Battus philenor butterflies. The roles of predation, nutrition and plant chemistry. - Ecol. Mon. 51: 1-20.

RICHMOND W., 1973 - Preparation and properties of a cholesterol oxidase from Nocardia sp. and its application to the enzymatic assay of total cholesterol in serum. - J. Clin. Chem. 19/12: 1350-1356.

RYAN C.A., 1990 - Protease inhibitors in plants: genes for improving defenses against insect and pathogens. - Annu. Rev. Phytopathol. 28: 425-449.

SATO P.M., LOPES A.R., JULIANO L., JULIANO M.A., TERRA W.R., 2008 - Subsite substrate specificity of midgut insect chymotrypsins. Insect Biochem. Mol. Biol. 38: 628-633.

SCRIBER J.M., SLANSKY J.R., 1981 - The nutritional ecology of immature insects. - Annu. Rev. Entomol. 26: 183-211.

SENTHIL-NATHAN S., CHUNG P.G., MURUGAN K., 2005 - Effect of biopesticides applied separately or together on nutritional indices of the rice leafolder Cnaphalocrocis medinalis. - Phytoparasitica. 33: 187-195.

SHARMA H.C., SHARMA K.K., SEETHARAMA N., ORTIZ R., 2000 Prospects for using transgenic resistance to insects in crop improvement. - Electron J. Biotech. 3: 1-20.

SHEIKHER C., SHARMA R., SHARMA K.C., 2001 - Consumption and utilization of cabbage by cabbage butterfly Pieris brassicae L. - J. Insect Sci. 14: 33-35.

SHEKARI M., JALALI SENDI J., ETEBARI K., ZIBAEE A. SHADPARVAR A., 2008 - Effects of Artemisia annua L. (Asteracea) on nutritional physiology and enzyme activities of elm leaf beetle, Xanthogaleruca luteola Mull. (Coleoptera: Chrysomellidae). - Pestic. Biochem. Physiol. 91: 66-74.

SHEPPARD C.A., FRIEDMAN S., 1990 - Influence of host plant, foliar phenology and larval dietary history on Lymantria dispar larval nutritional indices.- Entomol. Exp. Appl. 55: 247-255.

SIEGERT K.J., 1987 - Carbohydrate metabolism in Manduca sexta during late larval development. - J. Insect. Physiol. 33: 421-427.

SLANSKY F.J., 1993 - Nutritional ecology: the fundamental quest for nutrients. In: STAMP N.E. and CASEY T.E. (Eds.), Ecological and evolutionary constraints on foraging. - Chapman and Hall, New York: 29-91.

SLANSKY F.J. SCRIBER J.M., 1985 - Food consumption and utilization. In: KERKUT G.A., GILBERT L.I. (Eds.), Comprehensive insect physiology biochemistry and pharmacology, vol. 4. - Pergamon, 0xford: 87-163.

TERRA W.R., FERREIRA C., 1994 - Insect digestive enzymes: properties, compartmentalization and function. - Comp Biochem. Physiol. 109: 1-62.

THOMAS L., 1998 - Alanine aminotransferase (ALT), aspartate aminotransferase (AST). In: THOMAS L. (Ed.), Clinical laboratory diagnostics. Use and assessment of clinical laboratory results. - Books Verlagsgessellschaft, Frankfurt/Main: 55-65.

THOMPSON L.U., GABON J.E., 1986 - Effect of lectins on salivary and pancreatic amylase activities and the rate of starch digestión. - J. Food. Sci. 52: 1050-1054.

THOMPSON L.U., TENEBAUM A.V., HUI H., 1986 - Effect of lectins and the mixing of proteins on rate of protein digestibility. - J. Food Sci. 51: 150-152.

VINOKUROV K., TARANUSHENKO Y., KRISHNAN N., SEHNAL F., 2007 Proteinase, amylase, and proteinase-inhibitor activities in the gut of six cockroach species. - J. Insect Physiol. 53:794-802.

WALDBAUER G.P., 1968 - The consumption and utilization of food by insects. - Adv. Insect Physiol. 5: 229-288.

WATANABE H., KURIHARA Y., WANG Y.X., SHIMIZU T., 1988 - Mulberry pyralid, Glyhodes pyloalis: habitual host of non-occluded viruses pathogenic to the silkworm, Bombyx mori. - J. Invertebr. Pathol. 52: 401-408.

WILSON F., HUFFAKER C.B., 1976 - The physiology, scope and importance of biological control. In: HUFFAKER C.H., MESSENGER P.S. (Eds.), Theory and Practice of biological control. - Academic Press, New York: 3-15.

XUE M., PANG Y.H., WANG H.T., LI Q.L., LIU T.X., 2010 - Effects of four host plants on biology and food utilization of the cutworm, Spodoptera litura. - J. Insect. Sci. 10: 22.

ZHU J.H., ZHANG F.P., REN H.G., 2005 - Development and nutrition of Prodenia litura on four food plants. - Chinese Bull. Entomol. 42: 643-646.

ZIBAEE A., BANDANI A.A., KAFIL M., RAMZI S., 2008 - Characterization of $\alpha$-amylase in the midgut and the salivary glands of rice striped stem borer, Chilo suppressalis Walker (Lepidoptera: Pyralidae). - J. Asia-Pacific. Entomol. 11: 201-205. 